\title{
PEMBELAJARAN MENULIS PUISI BERORIENTASI MAJAS DENGAN MENGGUNAKAN METODE CREATIVE LEARNING PADA SISWA KELAS $X$ SMA AL-HIDAYAH CIPARAY KABUPATEN BANDUNG
}

\author{
Eggie Nugraha, M.Pd. ${ }^{1}$ \\ Dr. Asep Priatna, M.Pd. ${ }^{2}$ \\ ${ }^{1}$ Dosen FKIP Universitas Pasundan \\ ${ }^{2}$ Dosen STKIP Subang \\ 1eggienugraha@unpas.ac.id \\ 2asep_priatna@yahoo.co.id
}

\begin{abstract}
Today the development of Indonesian literature is growing rapidly. One effort to encourage the advancement of Indonesian literature is to improve the teaching of literary appreciation at every level of school. In order for students interested in learning to write poetry so as to develop creations and imagination. Based on the above background, the author is interested in conducting research on "Writing Poetry Oriented Learning Method Using Majas with Creative Learning in Class X SMA Al-Hidayah Ciparay. This study aims to determine the success of the author in implementing learning to write poetry oriented figure of speech with a method of creative learning in class $X$ SMA Al-Hidayah Ciparay, determine the ability of class X SMA Al-Hidayah Ciparay in writing poetry oriented figure of speech with a method of creative learning and knowing ketefektipan creative learning methods used in learning to write poetry oriented figure of speech in class X SMA Al-Hidayah Ciparay. Writer formulated hypotheses are: (1) The authors were able to carry out the figure of speech-oriented learning to write poetry using creative methods of learning in class X SMA Al-Hidayah Ciparay; (2) Grade X SMA Al-Hidayah Ciparay able to write poetry using a figure of speech-oriented creative methods of learning; (3) The method of creative learning is effectively used in learning to write poetry using a figure of speech-oriented creative methods of learning in class X SMA Al-Hidayah Ciparay. Research method that writer use is quasi-experiment method with research technique of literature study, trial, test and analysis.
\end{abstract}

Keywords: Poetry Writing, Majas, Creative Learning Method 


\begin{abstract}
ABSTRAK
Dewasa ini perkembangan sastra Indonesia semakin pesat. Salah satu upaya untuk mendorong majunya kesusastraan Indonesia yaitu meningkatkan pengajaran apresiasi sastra di setiap jenjang sekolah. Agar siswa tertarik dalam pembelajaran menulis puisi sehingga dapat mengembangkan kreasi dan imajinasi. Bertitik tolak dari latar belakang tersebut, penulis tertarik untuk mengadakan penelitian tentang "Pembelajaran Menulis Puisi Berorientasi Majas dengan Menggunakan Metode Creative Learning pada Siswa Kelas X SMA Al-Hidayah Ciparay. Penelitian ini bertujuan untuk mengetahui keberhasilan penulis dalam melaksanakan pembelajaran menulis puisi berorientasi majas dengan metode creative learning pada siswa kelas X SMA Al-Hidayah Ciparay, mengetahui kemampuan siswa kelas X SMA Al-Hidayah Ciparay dalam menulis puisi berorientasi majas dengan metode creative learning dan mengetahui ketefektipan metode creative learning digunakan dalam pembelajaran menulisi puisi berorientasi majas pada siswa kelas X SMA AIHidayah Ciparay. Hipotesis yang penulis rumuskan adalah : (1) Penulis mampu melaksanakan pembelajaran menulis puisi berorientasi majas dengan menggunakan metode creative learning pada siswa kelas X SMA AlHidayah Ciparay; (2) Siswa kelas X SMA Al-Hidayah Ciparay mampu menulis puisi berorientasi majas dengan menggunakan metode creative learning; (3) Metode creative learning efektif digunakan dalam pembelajaran menulis puisi berorientasi majas dengan menggunakan metode creative learning pada siswa kelas X SMA Al-Hidayah Ciparay. Metode penelitian yang penulis gunakan adalah metode eksperimen semu dengan teknik penelitian studi pustaka, uji coba, tes dan analisis.
\end{abstract}

Kata Kunci : Menulis Puisi, Majas, Metode Creative Learning 


\section{A. PENDAHULUAN}

Bahasa mempunyai fungsi yang sangat penting bagi manusia. Fungsi bahasa Belajar pada hakikatnya adalah perubahan yang terjadi di dalam diri seseorang setelah melakukan aktivitas tertentu. Walaupun pada kenyataannya tidak semua perubahan termasuk kategori belajar. Dalam belajar yang terpenting adalah proses bukan hasil yang diperolehnya. Artinya, belajar harus diperoleh dengan usaha sendiri, adapun orang lain itu hanya sebagai perantara atau penunjang dalam kegiatan belajar agar belajar itu dapat berhasil dengan baik.

Keberhasilan kegiatan belajar mengajar menentukan kesuksesan seorang guru dan sekolah dalam melaksanakan pendidikan. Oleh karena itu, seorang guru yang berhasil akan selalu memperhatikan tujuan pembelajaran yang sesuai dengan kurikulum. Keberhasilan kurikulum sangat dipengaruhi oleh kemampuan guru yang akan menerapkan dan mengaktualisasikan kurikulum tersebut. Dalam kurikulum mencakup beberapa aspek keterampilan diantaranya adalah keterampilan menyimak, berbicara, membaca, dan menulis.

Salah satu keterampilan yang sering digunakan dalam kegiatan belajar mengajar adalah keterampilan menulis. Menulis merupakan teknik seseorang untuk bisa mengungkapkan pikiran dan gagasan untuk melepaskan emosinya. Menurut Alwasilah (2007:43), menulis adalah kemampuan, kemahiran dan kepiawaian seseorang dalam menyampaikan gagasannya ke dalam sebuah wacana agar dapat diterima oleh pembaca yang heterogen baik secara intelektual dan sosial. Kita mengetahui bahwa ada orang yang dapat mengomunikasikan gagasannya hanya dengan cara menulis, namun ada pula orang yang hanya dapat mengungkapkannya dengan cara berbicara sesuai dengan keterampilan berbahasa yang dimiliki oleh seseorang.

Dalam kehidupan modern ini, jelas bahwa keterampilan menulis sangatlah dibutuhkan. Kiranya 
tindaklah terlalu berlebihan bila kita katakana bahwa keterampilan menulis merupakan suatu ciri dari orang yang terpelajar. Sehubungan dengan hal ini, Morsey dalam Tarigan (2008:4) mengatakan, bahwa menulis dipergunakan untuk melaporkan, memberitahukan, dengan maksud serta tujuan seperti itu hanya dapat dicapai dengan baik oleh orangorang yang dapat menyusun pikirannya dan mengutarakannya dengan jelas, kejelasan ini bergantung pada pikiran, organisasi, pemakaian kata-kata, dan struktur kalimat.

Berkaitan dengan sejumlah masalah di atas, salah satu tugas guru merupakan pendidik, sehubungan dengan itu Mulyasa (2008:53) berpendapat bahwa yang dimaksud dengan pendidikan sebagai agen pembelajaran (learning agent) antara lain sebagai fasilitator, motivator, pemacu, dan pemberi inspirasi belajar bagi peserta didik". Pernyataan tersebut kiranya merupakan tugas guru untuk dapat mengembangkan potensi siswa, dan juga mengembangkan kompetensi menulis yang perlu dilatih.

Sehubungan dengan menulis, dalam kurikulum banyak sekali materi yang mengajarkan tentang menulis. Salah satunya adalah menulis dalam bentuk puisi. Menulis puisi adalah membuat karya tulis yang melahirkan pikiran atau perasaan dari hasil perenungan suatu keadaan atau peristiwa yang dinikmati, dihayati, atau yang dialaminya.

Hasanuddin

(2002:5)

mengatakan, bahwa puisi merupakan perasaan yang imajinatif yaitu perasaan yang direkakan. Perasaan dan pikiran penyair yang masih abstrak dikonkretkan. Sedangkan menurut Waluyo mengungkapkan, bahwa puisi adalah salah satu bentuk kesusastraan yang mengungkapkan pikiran dan perasaan penyair secara imajinatif dan disusun dengan mengkonsentrasikan semua kekuatan bahasa yakni dengan mengkonsentrasikan struktur fisik dan struktur batinnya. 


Sementara Wordsworth
(dalam Pradopo, 2010:6)
mengemukakan puisi adalah
pernyataan perasaan yang
imajinatif, yaitu perasaan yang
direkakan atau diangankan. Untuk
mendapatkan kepuitisan dalam
sebuah puisi, diperlukan gaya
bahasa (figurative language)
Dengan adanya gaya bahasa in
menyebabkan puisi menjadi lebih
menarik perhatian, menimbulkan
kesegaran, dan menjadi lebih
hidup.

Bahasa

figuratif

menyebabkan puisi menjadi prismatis, artinya memancarkan banyak makna atau kaya akan makna (Waluyo, 1991:83). Bahasa figuratif disebut juga majas. Adapaun macam-macam majas antara lain metafora, simile, personifikasi, litotes, ironi, sinekdoke, eufemisme, repetisi, anafora, pleonasme, antitesis, alusio, klimaks, antiklimaks, satire, pars pro toto, totem pro parte, hingga paradoks.

Metode Creative Learning adalah metode pembelajaran yang bertujuan untuk menawarkan masukan bagi para praktisi dalam memikirkan tentang dukungan yang bisa berikan, baik yang bersipat praktis maupun teoritis, dalam membangun, mendifinisikan dan memperdalam pemahaman dan keyakinan mereka sendiri (Beetlestone, 2012:3).

Berdasarkan uraian di atas, penulis bermaksud mengadakan penelitian tentang pembelajaran menulis puisi berorientasi majas. Penelitian ini diwujudkan dalam sebuah judul "Menulis Puisi Berorientasi Majas dengan Menggunakan Metode Creative Learning Pada Siswa Kelas X SMA Al-Hidayah Ciparay Kabubapten Bandung".

\section{B. LANDASAN TEORI}

1. Menulis

\section{a. Pengertian Menulis}

Menulis adalah kegiatan berbahasa tidak secara langsung atau tidak secara tatap muka. Menulis adalah sebuah proses yang dapat mengembangkan kemampuan analisis dan membedakan berbagai hal secara akurat dan valid. Menulis akan meningkatkan rasa percaya diri. 
Menurut Alwasilah (2007:43), menulis adalah kemampuan, kemahiran, dan kepiawaian seseorang dalam menyampaikan gagasanya kedalam sebuah wacana agar dapat diterima oleh pembaca yang heterogen baik secara intelektual dan sosial berdasarkan pendapat di atas, penulis menyimpulkan bahwa menulis adalah suatu keterampilan berbahasa dalam bentuk pengungkapan ide, gagasan, pikiran, dan perasaan serta pengalaman yang dituangkan dengan bahasa tulis kedalam bentuk tulisan.

\section{b. Tujuan Menulis}

Setiap jenis tulisan
mengandung bebrapa tujuan,
tetapi karena tujuan itu sangat
beraneka ragam, bagi penulis yang belum berpengalaman ada baiknya memperhatikan kategori dibawah ini:

1) memberitahukan atau mengajar;

2) meyakinkan atau medesak;

3) mengutarakan atau mengekspresikan perasaan dan emosi yang berapi-api.

$$
\text { Menurut D'Angelo dalam }
$$
Tarigan (2008:25) dalam menulis perlu diperhatikan bahwa dalam praktiknya jelas sekali terlihat bahwa tujuan-tujuan yang telah disebutkan tadi sering bertumpang-tindih, dan setiap orang mungkin saja menambahkan tujuan-tujuan lain yang belum tercakup dalam daftar di atas. Tetapi dalam kebanyakan tujuan menulis, ada satu tujuan yang menonjol atau dominan, dan yang dominan inilah yang member atas keseluruhan tujuan tersebut.

Hugo Hartig dalam tarigan (2008: 25-26) merumuskan tujuan menulis, yaitu sebagai berikut.

1) Tujuan penugasan ,sebenarnya tidak memilki tujuan karena orang yang menulis melakukan nya karena tugas yang diberikan kepadanya.

2) Tujuan altruistik, penulis bertujuan untuk menyenangkan pembaca, menghindarkan kedudukan pembaca, ingin menolong pembaca memahami,menghargai perasaan dan penalaranya,ingin membuat hidup para pembaca lebih mudah dan lebih menyenangkan dengan karyanya itu 
3) Tujuan persuasif bertujuan meyakinkan para pembaca akan kebenaran gagasan yang diutarakan.

4) Tujuan informasional penulis bertujuan memberi informasi atau keterangan kepada para pembaca.

5) Tujuan pernyataan diri penulis bertujuan memperkenalkan atau menyatakan dirinya kepada pembaca.

6) Tujuan kreatif penulis bertujuan melibatkan dirinya dengan keinginan mencapai norma artistik,nilai-nilai kesenian.

7) Tujuan pemecahan masalah penulis bertujuan untuk memecahkan masalah yang dihadapi.

\section{c. Fungsi Menulis}

Menurut Tarigan (2008:22) pada prinsipnya fungsi utama dari tulisan adalah sebagai alat komuitas yang tidak langsung. Menulis sangat penting bagi pendidikan karena memudahkan para pelajar untuk berpikir. Juga dapat menolong kita berpikir secara kritis serta dapat memudahkankita merasakan dan menikmati hubungan-hubungan, memperdalam daya tanggap atau persepsi kita, memecahkan masalah-masalah yang kita hadapi, menyusun urutan bagi pengalaman

\section{Menulis Puisi}

\section{a. Pengertian Menulis Puisi}

Menulis merupakan suatu keterampilan berbahasa yang digunakan untuk komunikasi secar tidak langsung. Menulis merupakan kegiatan yang produktif dan ekspresif. Tarigan (2008:22) mengemukakan, bahwa menulis ialah menurunkan atau melukiskan lambang-lambang grafik yang menggambarkan suatu bahasa yang dipahami oleh seseorang, sehingga orang lain dapat membaca lambang-lambang grafik tersebut kalau meraka memahami bahasa dan gambaran grafik itu.

Menulis puisi merupakan kegiatan kompleks yang menuntut sejumlah kemampuan dan keterampilan. Kemampuan dalam menulis diantaranya kemampuan dalam mengungkapkan perasaan, ide maupun suatu gagasan dalam bentuk tulisan dengan menggunakan bahasa yang 
dipersingkat dan memiliki makna

kias serta memiliki rima dan ritma.

Hasanuddin (2002: 5)

mengatakan, bahwa puisi

merupakan perasaan yang

imajinatif yaitu perasaan yang

direkakan. Perasaan dan pikiran penyair yang masih abstrak

dikonkretkan.

Sedangkan

Jabrohim

(2009:

67)

mengungkapkan, bahwa menulis puisi merupakan suatu kegiatan seorang "intelektual", yakni kegiatan yang menuntut seseorang harus benar-benar cerdas, harus benar-benar menguasai bahasa, harus luas wawasannya, dan peka perasaannya.

Sedangkan menurut Kosasih (2004:247) mengungkapkan, bahwa dalam menulis sebuah puisi harus memperhatikan hal-hal berikut.

1) Puisi diciptakan dalam suasana perasaan yang intens yang menuntut pengucapan jiwa yang spontan dan padat. Dalam puisi, seseorang berbicara dan mengungkapkan dirinya sendiri secara ekspresif.

2) Penulis puisi hendaknya berdasarkan masalah atau berbagai hal yang menyentuh kesadaran penulis itu sendiri. Tema yang kita tulis untuk puisi hendaknya berangkat dari inspirasi diri sendiri yang khas, sekecil dan sesederhana apapun inspirasi itu.

3) Dalam menulis puisi kita memikirkan cara penyampaiannya. Cara penyampaian ide atau perasaan dalam berpuisi disebut gaya bahasa atau atau majas.

4) Gaya bahasa adalah susunan perkataan yang terjadi karena perasaan yang timbul atau hidup dalam hati penulis dan mampu menimbulkan suatu perasaan tertentu dalam hati pembaca.

5) Gaya bahasa membuat kalimatkalimat dalam puisi menjadi lebih hidup, bergerak, dan merangsang pembaca untuk memberi reaksi tertentu dan berkontemplasi atas apa yang dikemukakan penyair.

Berdasarkan pendapat di atas, penulis menyimpulkan bahwa menulis puisi adalah kemampuan untuk mengekspresikan pikiran, melalui tulisan yang dapat 
membangkitkan perasaan dan merangsang imajinasi panca indera dalam suasana yang berirama.

\section{b. Langkah-langkah Puisi}

Menulis puisi adalah kegiatan yang kompleks yang menuntut sejumlah kemampuan dan keterampilan. Oleh karena itu, supaya dapat menulis puisi sesuai dengan tuntutan di atas perlu diperhatikan langkah-langkah penulisannya.

$$
\text { Wiyanto }
$$

mengungkapkan, bahwa cara-cara menulis puisi adalah sebagai berikut: menentukan tema; mengembangkan tema; memilih kata-kata yang tepat; merangkai kata-kata yang estetis; dan mendayagunakan atau majas.

\section{Puisi}

\section{a. Pengertian Puisi}

Puisi dalam Kamus Besar Bahasa Indonesia edisi ketiga (2002:903), adalah ragam sastra yang bahasanya terikat oleh irama, mantra, rima, serta penyusunan larik dan bait. Puisi pun dapat diartikan sebagai gubahan bahasa yang bentuknya dipilih dan ditata secara cermat sehingga mempertajam kesadaran orang akan pengalaman dan membangkitkan respon khusus melalui penataan bunyi, irama dan makna luas. Sedangkan Aminuddin (2011: 134) mengungkapkan.

Bahwa secara etimologi istilah puisi berasal dari bahasa Yunani poeima 'membuat' atau poeistis 'pembuatan', dan dalam bahasa Inggris disebut poem atau poetry. Puisi diartikan "membuat" dan "pembuatan" karena lewat puisi pada dasarnya seorang telah menciptakan suatu dunia tersendiri, yang mungkin berisi pesan atau gambaran suasanasuasana tertentu, baik secara fisik maupun batin.

Sedangkan menurut Pradopo (2010:7) mengungkapkan, bahwa puisi itu mengekspresikan pemikiran yang membangkitkan perasaan, yang merangsang imajinasi panca indera dalam susunan yang berirama. Selain itu, Slametmuljana dalam Waluyo (1991:23) menyatakan, bahwa puisi merupakan bentuk kesusastraan yang menggunakan 
pengulangan suara sebagai ciri khasnya. Pengulangan kata itu menghasilkan rima, ritma, dan musikalitas. Jika pengertian itu ditinjau dari segi bentuk batin puisi maka Herbert Spencer mengatakan bahwa puisi merupakan bentuk pengucapan gagasan yang bersifat emosional dengan mempertimbangkan efek keindahan.

Setelah mempelajari beberapa pengertian di atas, dapat ditarik kesimpulan bahwa puisi adalah bentuk kesusastraan yang ditulis dengan bahasa yang puitis dan kaya makna. Bahasa yang digunakan dalam puisi berbeda dengan bahasa yang digunakan sehari-hari. Puisi menggunakan bahasa yang ringkas, namun maknanya singkat dan kaya katakata. Kata-kata yang digunakannya adalah kata-kata konotatif, yang mengandung banyak penafsiran dan pengertian.

Disamping itu puisi dapat membangkitkan daya khayal serta bisa menarik perhatian orang banyak.

\section{b. Ciri-Ciri Puisi}

Slametmuljana dalam Pradopo (2010:7) mengungkapkan bahwa puisi berbeda dengan prosa. Perbedaan pokok antara puisi dan prosa antara lain sebagai berikut.

1) Kesatuan-kesatuan

korespondensi prosa yang pokok ialah kesatuan sin-taksis; kesatuan korespon-densi puisi resminya bikan kesatuan sintaksis- esatuan akustis;

2) Di dalam puisi korespon-densi dari corak tertentu, yang terdiri dari kesatuan-kesatuan tertentu pula, meliputi seluruh puisi dari semula sampai akhir. Kesatuan ini disebut baris sajak;

3) Di dalam baris sajak ada periodisitas dari mula sampai akhir.

Melengkapi pendapat di atas, Waluyo (1991:25) mengemukakan, ciri-ciri puisi adalah sebagai berikut.

1) Dalam puisi terjadi pengkonsentrasian atau pemadatan segala unsur kekuatan bahasa;

2) Dalam penyusunannya, unsurunsur itu dirapikan, diperbagus, 
Didaktik : Jurnal Pendidikan Guru Sekolah Dasar, ISSN : 24775673

Sekolah Tinggi Keguruan dan IImu Pendidikan Subang Volume II Nomor 2, Juli 2017

diatur sebaik-baiknya dengan memperhatikan irama dan bunyi;

3) Ungkapan pikiran dan perasaan penyair yang berdasarkan mood atau pengalaman jiwa dan bersifat imajinatif;

4) Bahasa yang digunakan bersifat konotatif; hal ini ditandai dengan kata konkret lewat pengimajian, pelambangan, dan pengiasan, atau dengan kata lain dengan kata konkret dan Atau majas.

5) Bentuk fisik dan batin merupakan kesatuan yang bulat dan utuh menyaturaga tidak dapat dipisahkan dan merupakan kesatuan yang padu.

Dapat ditarik kesimpulan dari pendapat para ahli bahwa ciri-ciri pusi secara bahasa menggunakan bahasa konotatif serta menggunakan nilai-nilai estetika dalam kaidah kebahasaan, selain itu bentuk fisik dan batin puisi merupakan hal yang menarik dalam puisi dan tidak dapat dipisahkan dari puisi.

\section{c. Unsur-unsur Puisi}

Secara garis besar, unsurunsur puisi terbagi ke dalam dua macam, yakni struktur fisik dan struktur batin. Menurut Jabrohim (2009:35-67), berpendapat bahwa unsur-unsur puisi sebagai berikut;

1) Unsur fisik, Unsur fisik meliputi hal-hal berikut, Diksi (pemilihasn kata); Pencitraan; Atau majas;

Rima dan Irama; dan Tipografi

2) Unsur batin

Unsur-unsur yang termasuk dalam struktur batin puisi antara lain adalah tema, perasaan penyair, nada, suasana dan amanat. Untuk memberikan gambaran yang lebih jelas, berikut ini dikemukakan mengenai struktur batin dari puisi antara lain sebagai berikut.Tema; Perasaan; Nada; Suasana; dan Amanat.

Dari pendapat diatas dapat disimpulkan bahwa puisi terbagi menjadi dua unsur, yaitu; unsur fisik dan unsur batin. Kedua unsur tersebut tidak dapat dipisahkan karena kedua unsur tersebut saling keterkaitan.

\section{Majas}

\section{a. Pengertian Majas}

Majas atau gaya bahasa adalah pemanfaatan kekayaan bahasa, pemakaian ragam tertentu untuk memperoleh efek-efek 
tertentu, keseluruhan ciri bahasa sekelompok penulis sastra dan cara khas dalam menyampaikan pikiran dan perasaan, baik secara lisan maupun tertulis, sedangkang menurut $\mathrm{KBBI}$ majasadalah cara melukiskan sesuatu dengan jalan menyamakannya dengan sesuatu yg lain; kiasan.

\section{b. Ragam Majas}

Gaya Bahasa dapat ditinjau dari bermacam-macam sudut pandang. Oleh sebab itu, sulit diperoleh kata sepakat mengenai suatu pembagian yang bersifat menyeluruh dan dapat diterima oleh semua pihak, (Keraf 1999:115).

\section{Gaya bahasa dapat} dikategorikan dalam berbagai cara. Lain penulisan lain pula klasifikasi yang dibuatnya. Sesuai dengan maksud dan tujuan yang hendak dicapai maka gaya bahasa yang berbagai macam itu di bagi menjadi empat kelompok, (Tarigan, 2009: 4-191).

Sehubungan majas yang digunakan penulis dalam penelitian berpokus pada majas perbandingan khususnya majas perumpamaan, metafora dan personifikasi maka majas yang akan diuraikan tiga majas ini.

1) Perumpamaan

Perumpamaan adalah perbandingan dua hal yang pada hakikatnya berlainan dan yang sengaja kita anggap sama. Contoh: Kau dengan dia tak ubahnya seperti air dengan minyak, Kelakuan kau bak cacing kepanasan.

2) Metafora

Metafora ialah perbandingan yang implisit jadi tanpa kata seperti atau sebagai di antara dua hal yang berbeda, (Dale dalam Tarigan, 2009:15). Sedangkan menurut Tarigan (2009:15) metafora adalah sejenis gaya bahasa perbandingan yang paling singkat, padat, tersusun rapi. Contoh: jinak-jinak. Dasar kau mata keranjang

3) Personifikasi

Personifikasi adalah jenis majasyang melekatkan sifat-sifat insani kepada benda yang tidak bernyawa dan ide yang abstrak. Contoh: hujan membandingkan tanaman, mentari mencubit wajahku, dan pepohonan tersenyum riang. 
Didaktik : Jurnal Pendidikan Guru Sekolah Dasar, ISSN : 24775673

Sekolah Tinggi Keguruan dan IImu Pendidikan Subang Volume II Nomor 2, Juli 2017

\section{METODE PENELITIAN}

Metode yang digunakan dalam penelitian ini adalah kuasi eksperimen. Metode ini dimaksudkan untuk menyelidiki kemungkinan sebab akibat dengan cara mengenakan pada kelompok eksperimen dan membandingkan hasilnya dengan kelompok kontrol yang tidak dikenai kondisi perlakuan. Adapun tipe kuasi yang akan dipakai adalah tipe Nonquivalent Control Group Design. Menurut Sugiono (2009: 116) desain ini hampir sama dengan pretest-posttest control group design, hanya pada desain ini kelompok eksperimen maupun kontrol tidak dipilih secara random.

\section{HASIL PENELITIAN}

Berdasarkan hasil analisis prates dan pascates , maka penulis memiliki hasil penilaian yang disesuaikan dengan kriteria yang telah dibuat. Hal tersebut untuk memberikan kejelasan dalam hasil penilaian akhir. Selanjutnya Penulis akan mnyajikan hasil penilaian akhir prates dan pascates dalam bentuk tabel.
Tabel 1 Hasil Prates Siswa Kelas X SMA AL-HIDAYAH CIPARAY

\begin{tabular}{|c|c|c|c|c|c|c|c|}
\hline \multirow{2}{*}{ ] } & \multirow{2}{*}{$\begin{array}{l}\text { Nama } \\
\text { Siswa }\end{array}$} & \multicolumn{4}{|c|}{ Aspek yang Dinilai } & \multirow{2}{*}{$\begin{array}{l}\text { Skor } \\
\text { Total }\end{array}$} & \multirow{2}{*}{ Nila } \\
\hline & & 1 & 2 & 3 & 4 & & \\
\hline 1. & $\begin{array}{l}\text { Agus } \\
\text { Mulyana }\end{array}$ & 10 & 0 & 0 & 0 & 10 & 1,3 \\
\hline 2. & $\begin{array}{l}\text { Agus } \\
\text { Murdiana }\end{array}$ & 10 & 0 & 0 & 0 & 10 & 1,3 \\
\hline 3. & $\begin{array}{l}\text { Ahmad } \\
\text { Nurul S }\end{array}$ & 8 & 0 & 0 & 10 & 18 & 2,4 \\
\hline 4. & $\begin{array}{l}\text { Anggi } \\
\text { Akbar }\end{array}$ & 10 & 0 & 0 & 10 & 20 & 2,7 \\
\hline 5. & $\begin{array}{l}\text { Dede } \\
\text { Kanifa } \\
\end{array}$ & 10 & 0 & 0 & 10 & 20 & 2,7 \\
\hline 6. & Denan M & 10 & 0 & 0 & 5 & 15 & 2,0 \\
\hline 7. & Eldi G & 10 & 0 & 0 & 0 & 10 & 1,3 \\
\hline 8. & $\begin{array}{l}\text { Elis } \\
\text { Nuryanti }\end{array}$ & 10 & 0 & 0 & 10 & 20 & 2,7 \\
\hline 9. & Fitriani & 10 & 0 & 0 & 15 & 25 & 3,3 \\
\hline 10. & $\begin{array}{l}\text { Imut } \\
\text { Sundari }\end{array}$ & 8 & 0 & 0 & 10 & 18 & 2,4 \\
\hline 11. & Indriyani & 8 & 3 & 5 & 15 & 31 & 4,1 \\
\hline 12. & $\begin{array}{l}\text { Intan Nuria } \\
\mathrm{P}\end{array}$ & 10 & 3 & 0 & 10 & 23 & 3,1 \\
\hline 13. & Ira Mutiara & 10 & 0 & 0 & 10 & 20 & 2,7 \\
\hline 14. & $\begin{array}{l}\text { Mutia } \\
\text { Rubiokta }\end{array}$ & 10 & 0 & 0 & 15 & 25 & 3,3 \\
\hline 15. & $\begin{array}{l}\text { Reni } \\
\text { Karmila } \\
\end{array}$ & 10 & 0 & 0 & 15 & 25 & 3,3 \\
\hline 16. & $\begin{array}{l}\text { Rina } \\
\text { Risnawati }\end{array}$ & 10 & 0 & 0 & 5 & 15 & 2,0 \\
\hline 17. & $\begin{array}{l}\text { Rudi } \\
\text { Khoerudin }\end{array}$ & 10 & 6 & 5 & 10 & 31 & 4,1 \\
\hline 18. & $\begin{array}{l}\text { Siti Mulyani } \\
\text { Fauziah }\end{array}$ & 10 & 6 & 5 & 15 & 36 & 4,8 \\
\hline 19. & $\begin{array}{l}\text { Siti } \\
\text { Wafiyah }\end{array}$ & 10 & 3 & 5 & 15 & 33 & 4,4 \\
\hline 20. & Solihin & 10 & 0 & 0 & 10 & 20 & 2,7 \\
\hline 21. & $\begin{array}{l}\text { Soni } \\
\text { Mumin M }\end{array}$ & 10 & 12 & 5 & 15 & 42 & 5,6 \\
\hline 22. & Tina & 10 & 0 & 0 & 0 & 10 & 1,3 \\
\hline 23. & Wida & 10 & 0 & 0 & 15 & 25 & 3,3 \\
\hline 24. & Wildan $\mathrm{H}$ & 10 & 0 & 0 & 0 & 10 & 1,3 \\
\hline 25. & $\begin{array}{l}\text { Wildan } \\
\text { Taufik } \\
\end{array}$ & 10 & 0 & 0 & 10 & 20 & 2,7 \\
\hline \multicolumn{6}{|c|}{ Jumlah } & 532 & 70,9 \\
\hline \multicolumn{6}{|c|}{ Rata-rata } & 21,3 & 2,8 \\
\hline
\end{tabular}


Keterangan

1 : Kesesuaian isi puisi

berasarkan tema dan judul

2 : Kesesuaian diksi dengan judul

3 : Jumlah penggunaan majas

4 : Kesesuaian pemilihan kata

Berdasarkan tabel di atas, diketahui bahwa nilai terendah pretes adalah 1,3 sebanyak 5 siswa, dan nilai yang paling tinggi adalah 5,6 sebanyak 1 orang. Sedangkan nilai rata-rata yang diperoleh adalah 2,8. Sekaitan dengan data pretes di atas, maka penulis akan menyajikan dan nilai siswa secara berurutan mulai dari yang terendah sampai teringgi.

Berdasarkan tabel di atas, nilai pretes terendah hingga tertinggi adalah nilai 1,3 ada 5 siswa, nilai 2,0 ada 2 siswa, nilai 2,4 ada 2 siswa, nilai 2,7 ada 6 siswa, nilai 3,1 ada 1 siswa, nilai 3,3 ada 4 siswa, nilai 4,1 ada 2 siswa, nilai 4,4 ada 1 siswa, nilai 4,8 ada 1 siswa, dan nilai 5,6 ada 1 siswa.
Tabel 4.7 Hasil Posttest

Siswa Kelas X SMA Al-Hidayah

Ciparay

\begin{tabular}{|c|c|c|c|c|c|c|c|}
\hline \multirow[t]{2}{*}{ No } & \multirow{2}{*}{$\begin{array}{l}\text { Nama } \\
\text { Siswa }\end{array}$} & \multicolumn{4}{|c|}{ Aspek yang Dinilai } & \multirow{2}{*}{$\begin{array}{l}\text { Skor } \\
\text { Total }\end{array}$} & \multirow{2}{*}{ Nila } \\
\hline & & 1 & 2 & 3 & 4 & & \\
\hline \multirow[b]{2}{*}{1.} & Agus & 1 & 1 & & 1 & & \\
\hline & Mulyana & 0 & 2 & 25 & 5 & 62 & 8,3 \\
\hline \multirow[b]{2}{*}{2.} & Agus & 1 & 1 & & 1 & & \\
\hline & Murdiana & 0 & 2 & 20 & 5 & 57 & 7,6 \\
\hline \multirow[b]{2}{*}{3.} & Ahmad & & 1 & & 2 & & \\
\hline & Nurul S & 8 & 2 & 25 & 0 & 65 & 8,7 \\
\hline \multirow[b]{2}{*}{4.} & Anggi & & 1 & & 2 & & \\
\hline & Akbar & 8 & 2 & 20 & 5 & 65 & 8,7 \\
\hline \multirow[b]{2}{*}{5.} & Dede & & 1 & & 1 & & \\
\hline & Kanifa & 8 & 2 & 25 & 5 & 60 & 8,0 \\
\hline \multirow[b]{2}{*}{6.} & & 1 & 1 & & 2 & & \\
\hline & Denan M & 0 & 2 & 20 & 0 & 62 & 8,3 \\
\hline \multirow[b]{2}{*}{7.} & & & 1 & & 1 & & \\
\hline & Eldi $G$ & 4 & 2 & 25 & 5 & 56 & 7,5 \\
\hline \multirow{2}{*}{8.} & Elis & & 1 & & 1 & & \\
\hline & Nuryanti & 8 & 2 & 25 & 0 & 55 & 7,3 \\
\hline \multirow[b]{2}{*}{9.} & & 1 & 1 & & 1 & & \\
\hline & Fitriani & 0 & 2 & 20 & 5 & 57 & 7,6 \\
\hline \multirow[b]{2}{*}{10.} & Imut & 1 & 1 & & 1 & & \\
\hline & Sundari & 0 & 2 & 25 & 5 & 62 & 8,3 \\
\hline \multirow[b]{2}{*}{11.} & & 1 & 1 & & 1 & & \\
\hline & Indriyani & 0 & 2 & 20 & 5 & 57 & 7,6 \\
\hline \multirow[b]{2}{*}{12.} & Intan & & 1 & & 1 & & \\
\hline & Nuria $P$ & 8 & 2 & 25 & 5 & 60 & 8,0 \\
\hline \multirow[b]{2}{*}{13.} & Ira & & 1 & & 1 & & \\
\hline & Mutiara & 8 & 2 & 25 & 5 & 60 & 8,0 \\
\hline \multirow[b]{2}{*}{14.} & Mutia & 1 & 1 & & 2 & & \\
\hline & Rubiokta & 0 & 2 & 25 & 0 & 67 & 8,9 \\
\hline \multirow[b]{2}{*}{15.} & Reni & & 1 & & 2 & & \\
\hline & Karmila & 8 & 2 & 25 & 0 & 65 & 8,7 \\
\hline \multirow{2}{*}{16.} & Rina & & 1 & & 1 & & \\
\hline & Risnawati & 8 & 2 & 25 & 5 & 60 & 8,0 \\
\hline \multirow{3}{*}{17.} & Rudi & & & & & & \\
\hline & Khoerudi & 1 & 1 & & 1 & & \\
\hline & $\mathrm{n}$ & 0 & 2 & 25 & 5 & 62 & 8,3 \\
\hline \multirow[b]{3}{*}{18.} & Siti & & & & & & \\
\hline & Mulyani & 1 & 1 & & 2 & & \\
\hline & Fauziah & 0 & 2 & 25 & 5 & 72 & 9,6 \\
\hline & Siti & & 1 & & 2 & & \\
\hline 19. & Wafiyah & 8 & 2 & 25 & 0 & 65 & 8,7 \\
\hline & & & 1 & & 1 & & \\
\hline 20. & Solihin & 8 & 2 & 25 & 0 & 55 & 7,3 \\
\hline
\end{tabular}




\begin{tabular}{|c|c|c|c|c|c|c|c|}
\hline \multirow[t]{2}{*}{ No } & \multirow{2}{*}{$\begin{array}{l}\text { Nama } \\
\text { Siswa }\end{array}$} & \multicolumn{4}{|c|}{ Aspek yang Dinilai } & \multirow{2}{*}{$\begin{array}{l}\text { Skor } \\
\text { Total }\end{array}$} & \multirow{2}{*}{ Nilai } \\
\hline & & 1 & 2 & 3 & 4 & & \\
\hline \multirow[b]{2}{*}{21.} & Soni & & 1 & & 2 & & \\
\hline & Mumin M & 8 & 2 & 25 & 0 & 65 & 8,7 \\
\hline \multirow[b]{2}{*}{22.} & & 1 & 1 & & 1 & & \\
\hline & Tina & 0 & 2 & 25 & 5 & 62 & 8,3 \\
\hline \multirow{2}{*}{23.} & & & 1 & & 1 & & \\
\hline & Wida & 8 & 2 & 25 & 5 & 60 & 8,0 \\
\hline \multirow{2}{*}{24.} & & & 1 & & 1 & & \\
\hline & Wildan $\mathrm{H}$ & 8 & 2 & 25 & 5 & 60 & 8,0 \\
\hline \multirow{6}{*}{25.} & Wildan & & 1 & & 1 & & \\
\hline & Taufik & 8 & 2 & 25 & 5 & 60 & 8,0 \\
\hline & \multirow{2}{*}{\multicolumn{5}{|c|}{ Jumlah }} & & 204, \\
\hline & & & & & & 1531 & 1 \\
\hline & \multirow{2}{*}{\multicolumn{5}{|c|}{ Rata-rata }} & 61,2 & \\
\hline & & & & & & 4 & 8,2 \\
\hline
\end{tabular}

Keterangan

1 : Kesesuaian isi puisi

berasarkan tema dan judul

2 : Kesesuaian diksi dengan judul

3 : Jumlah penggunaan majas

4 : Kesesuaian pemilihan kata

dalam menulis puisi

Berdasarkan tabel di atas, diketahui bahwa nilai terendah pascates adalah 7,3 sebanyak 2 siswa, dan nilai yang paling tinggi adalah 9,6 sebanyak 1 orang. Sedangkan nilai rata-rata yang diperoleh adalah 8,2. Sekaitan dengan data pascates di atas, maka penulis akan menyajikan dan nilai siswa secara berurutan mulai dari yang terendah sampai teringgi.
Berdasarkan tabel di atas, nilai pascates terendah hingga tertinggi adalah nilai 7,3 ada 2 siswa, nilai 7,5 ada 1 siswa, nilai 7,6 ada 3 siswa, nilai 8 ada 7 siswa, nilai 8,3 ada 5 siswa, nilai 8,7 ada 5 siswa, nilai 8,9 sebanyak 1 siswa, dan nilai 9,6 ada 1 siswa.

\section{E. SIMPULAN}

1. Penulis mampu melaksanakan pembelajaran menulis puisi berorientasi majas dengan menggunakan metode creative learning pada siswa kelas $X$ SMA Al-Hidayah Ciparay. Hal ini dibuktikan dari hasil penilaian guru Bahasa Indonesia terhadap persiapan dan pelaksanaan pengajaran yang penulis lakukan. Penulis memperoleh nilai rata-rata untuk persiapan pembelajaran 3,87, dan pada pelaksanaan pembelajaran penulis mendapat nilali rata-rata 3,83 yang termasuk ke dalam kategori (A) baik sekali. Berdasarkan penilaian tersebut, diperoleh kesimpulan bahwa penulis berhasil mengadakan penelitian tentang pembelajaran menulis 
puisi berorientasi majas dengan menggunakan metode creative learning pada siswa kelas $\mathrm{X}$ SMA Al-Hidayah Ciparay Kab. Bandung.

2. Siswa mampu menulis puisi berorientasi majas dengan menggunakan metode creative learning setelah pembelajaran berlangsung. Hal ini dapat dijawab dari hasil analisis data nilai prates dengan skor ratarata 2,8 dan nilai pascates dengan skor rata-rata 8,18 . Dengan demikian, ada peningkatan belajar sebesar $21,6 \%$. Hasil penelitian tersebut menunjukan, bahwa siswa kelas X SMA Al-Hidayah Ciparay Kab. Bandung mampu menulis puisi berorientasi majas dengan menggunakan metode creative learning.

3. Metode creative learning efektif digunakan dalam pembelajaran menulis puisi berorientasi gaya bahasa metafora. Hal ini dapat dilihat berdasarkan hasil uji statistik dengan $t_{\text {hitung }} \geq t_{\text {tabel }}$ yaitu $8,03 \geq 2,04$ dalam tingkat kepercayaan $95 \%$ dengan derajat kebebasan 24. Hal ini membuktikan, bahwa metode creative learning efektif digunakan dalam pembelajaran menulis puisi berorientasi majas.

Dari hasil pembuktian tersebut, dapat disimpulkan bahwa pembelajaran pembelajaran menulis puisi berorientasi majas dengan menggunakan metode creative learning menunjukan keberhasilan.

\section{DAFTAR PUSTAKA}

Alwasilah dan Senny Suzanna.(2007). Pokoknya Menulis. Bandung: Jakarta

Aminuddin. (2011). Pengantar Apresiasi Karya Sastra. Bandung: Sinar Baru Algesindo.

Beetlestone, F. (2012). Creative Learning. Bandung: Nusa Media Finoza, L. (2009). Komposisi Bahasa Indonesia. Jakarta: Diksi Insan Mulia.

Hasanuddin. (2002). Membaca dan Menilai Sajak. Bandung: Angkasa. 
Jabrohim, dkk (2009). Cara Subana. (2009). Dasar-dasar Menulis Kreatif. Yogyakarta: Penelitian Ilmiah. Bandung:

Pustaka Pelajar.

Pustaka Setia.

Keraf. (1999). Diksi dan Gaya

Bahasa. Jakarta: Gramedia.

Sumardjo. (1988). Apresiasi

Kesusastraan. Jakarta:

Kosasih. (2004). Ketatabahasaan

Gramedia. (2008).

dan kesusastraan. Bandung:

Kurikulum Tingkat Satuan

Yrama Widya.

Pendidikan. Yogyakarta:

Majid. (2009). Perencanaan

Pustaka Pelajar.

Pembelajaran. Bandung:

Rosda.

Mulyasa, E. (2006). Kurikulum

Tingkat Satuan Pendidikan.

Bandung: Rosda.

Mulyasa, E (2008). Standar Kompetensi dan Seritikasi Guru. Bandung: Remaja Rosdakarya

Narwati, S. (2011). Creative Learning. Yogyakarta: Familia

Nurgiyantoro, B. (2009). Penilaian dalam Pengajaran Bahasa dan Sastra. Yogyakarta: BPFE

Nurhayatin, T. (2009). Penilaian

Pembelajaran Bahasa dan

Sastra Indonesia Berbasis

Kelas. Bandung: Prisma

Press

Pradopo. (2010). Pengkajian Puisi.

Yogyakarta: Gajah Mada

University Press. 
Didaktik : Jurnal Pendidikan Guru Sekolah Dasar, ISSN : 24775673

Sekolah Tinggi Keguruan dan IImu Pendidikan Subang Volume II Nomor 2, Juli 2017 